Mức độ trầm cảm được đánh giá bằng thang điểm Hamilton (Hamilton Rating Scale for Depression: HRSD). Nghiên cứu cho thấy nồng độ Dopamin trong huyết tương có tương quan thuận chiều đáng kể với tổng điểm thang HRSD $(r=0,79 ; p<0,01)$, qua đó cho thấy nồng độ $D A$ huyết tương có thể phản ánh mức độ trầm trọng của chứng trầm cảm [7].

Nghiên cứu của chúng tôi trên 62 bệnh nhân trầm cảm, trong đó có 6 trường hợp (chiếm $9,68 \%$ ) có triệu chứng loạn thần và tỉ lệ nam giới chiếm $51,61 \%$, sử dụng thang điểm Beck (BDI) để khảo sát thay đổi mức độ trầm cảm, kết quả thấy không tồn tại tương quan giữa nồng độ Dopamin huyết tương với giá trị điểm Beck tương ứng. Như vậy nghiên cứu của chúng tôi không phù hợp với tác giả Hamner và Diamond (1996) vì khônng đồng nhất các đặc điểm của mẫu nghiên cứu như tî lệ nam giới (100\% so với $51,61 \%)$, tỉ lệ có loạn thần ( $0 \%$ so với $9,68 \%)$ và thang đánh giá trầm cảm (HRSD so với $\mathrm{BDI}$ ).

Một số nghiên cứu gần đây cho thãy chỉ khoảng 40\% nồng độ HVA trong huyết tương có nguồn gốc từ chuyển hóa Dopamin trong hệ thần kinh trung ương, đây là căn cứ lý giải cho sự khác biệt giữa kết quả nghiên cứu của chúng tổi với nghiên cứu của các tác giả trên [8].

\section{KẾT LUÂ̂N}

- Nồng độ Dopamin huyết tương ở nhóm bệnh nhân trầm cảm chủ yếu thấp hơn so với nhóm chứng, nhưng sự khác biệt không có ý nghĩa thống kê $(24,96 \pm 12,55 \mathrm{pg} / \mathrm{ml}$ và $28,72 \pm 11,95 \mathrm{pg} / \mathrm{ml}, \mathrm{p}>0,05)$. Nồng độ Dopamin huyết tương ở nhóm bệnh nhân trầm cảm chủ yễu có loạn thần $(18,26 \pm 13,32 \mathrm{pg} / \mathrm{ml})$ thấp hơn so với nhóm trầm cảm không có loạn thần $(25,68 \pm 12,38 \mathrm{pg} / \mathrm{ml})$, sự khác biệt cũng không có ý nghĩa thống kê với p $>0,05$.

- Nồng độ Dopamin huyết tương ở nhóm nghiên cứu (nhóm bệnh và nhóm chứng) không phụ thuộc vào giới tính và độ tuổi.

- Không tồn tại tương quan giữa nồng độ Dopamin huyết tương và điểm Beck ở nhóm bệnh nhân trầm cảm chủ yếu.

\section{TÀI LIÊU THAM KHẢO}

1. American Psychiatric Association, Diagnostic and Statistical manual of mental disorder, (2013), 155-188.

2. Gotlib I.H, Hammen C.L, Handbook of Depression, New York, (2009), 187-218.

3. Belujon P., Grace A. A. ,"Dopamine System Dysregulation in Major Depressive Disorders", Int J Neuropsychopharmacol, (2017), 20(12), 1036-1046.

4. Wyatt R. J., Portnoy B., Kupfer D. J. et al., "Resting plasma catecholamine concentrations in patients with depression and anxiety", Arch Gen Psychiatry, (1971), 24(1), 65-70.

5. Mazure C. M., Bowers M. B., Jr., Hoffman F., Jr. et al, "Plasma catecholamine metabolites in subtypes of major depression", Biol Psychiatry, (1987), 22(12), 1469-72.

6. Devanand D. P., Bowers M. B., Jr., Hoffman F. J., Jr. et al, "Elevated plasma homovanillic acid in depressed females with melancholia and psychosis", Psychiatry Res, (1985), 15(1), 1-4

7. Hamner M. B., Diamond B. I., "Plasma dopamine and norepinephrine correlations with psychomotor retardation, anxiety, and depression in non-psychotic depressed patients: a pilot study", Psychiatry Res, (1996), 64(3), 209-11.

8. Kendler K. S., Heninger G. R., Roth R. H. "Influence of dopamine agonists on plasma and brain levels of homovanillic acid", Life Sci, (1982), 30(24), 2063-9.

\title{
NGHIÊN CỨU NỒNG Độ NT-proBNP HUYẾT THANH VÀ MỐI LIÊN QUAN VớI MỨC Độ TỔN THƯƠ'NG ĐộNG MACH VÀNH BẰNG THANG ĐIỂM SYNTAX II Ở BÊ̂NH NHÂN NHỒI MÁU CƠ TIM CẤP
}

\section{TÓM TẮT}

\author{
${ }^{1}$ Học viện Quân y \\ ²Bệnh viện Đa khoa Hà Đông \\ ${ }^{3}$ Bênh viên Quân y 103 \\ Chiu trách nhiêm chính: Trần Đức Hùng \\ Email: tranduchung2104@gmail.com \\ Ngày nhận bài: 16.9.2021 \\ Ngày phản biện khoa học: 12.11.2021 \\ Ngày duyệt bài: 25.11.2021
}

\section{Lê Phước Trung ${ }^{1}$, Đỗ Hũu Nghị ${ }^{2}$, Trần Đức Hùng ${ }^{3}$}

Mục tiêu: Đánh giá nồng độ NT-proBNP huyết thanh và mối liên quan với mức độ tổn thương động mạch vành bằng thang điểm SYNTAX II ở bệnh nhân (BN) nhồi máu cơ tim (NMCT) cấp. Đối tượng và phương pháp nghiên cứu: Nghiên cứu mổ tả cắt ngang 69 BN được chẩn đoán xác định NMCT cấp được chụp động mạch vành (ĐMV) qua da tại Trung Tâm Tim mạch, Bềnh viên Quân y 103 từ tháng $1 / 2020$ đến tháng $6 / 2021$. Kết quả: Độ tuổi trung bình của nhóm nghiên cứu là $65,8 \pm 11,2$. Nam giới chiếm tỉ lệ cao (76,8\%). Giá trị trung vị của nồng độ NT-proBNP là 242,7 (Min 82,2; Max 871,5) pg/mi. 
Trung vị NT-proBNP ở nhóm có tổn thương 2 nhánh $(310,9 \mathrm{pg} / \mathrm{ml})$ và 3 nhánh $(746,1 \mathrm{pg} / \mathrm{ml})$ cao hơn nhóm tổn thương 1 nhánh động mạch vành $(89,2$ $\mathrm{pg} / \mathrm{ml}$ ) có ý nghĩa. Trung vị NT-proBiNP ở nhóm có điểm SYNTAX < $23(214,8 \mathrm{pg} / \mathrm{ml})$ thấp hơn nhóm có điểm SYNTAX $\geq 23(1124,7 \mathrm{pg} / \mathrm{ml})$ có ý nghĩa. Điểm SYNTAX có mối tương quan thuận khá chặt với nồng độ NT-proBNP huyết thanh $(r=0,62, p<0,05)$. Điểm cắt của nồng độ NT-proBNP dự báo điểm SYNTAX $\geq$ 23 là 496,85 pg/ml (độ nhạy 75\%; độ đặc hiệu $77,4 \% ; p<0,05)$. Kết luận: Nghiên cứu của chúng tôi cho thấy nồng độ NT-proBNP ở BN NMCT cấp tương quan khá chăt chẽ̃ với mức độ tổn thương động mạch vành theo thang điểm SYNTAX II và điểm cắt của nồng độ NT-proBNP dự báo điểm SYNTAX $\geq 23$ là $496,85 \mathrm{pg} / \mathrm{ml}$.

Tư khóa: Nhồi máu cơ tim cấp, NT-proBNP, điểm SYNTAX II.

\section{SUMMARY}

STUDY ON SERUM NT-prOBNP LEVELS AND ASSOCIATION WITH SEVERITY OF CORONARY ARTERY DISEASE ASSESSED BY SYNTAX II SCORE IN PATIENTS WITH ACUTE MYOCARDIAL INFARCTION

Objectives: To evaluate serum NT-proBNP levels and to investigate the relationship between NTproBNP and SYNTAX II score, which is a measure of the complexity of coronary artery disease in patients with acute myocardial infarction (MI). Materials and methods: The descriptive cross-sectional study on 69 patients with acute MI, who underwent coronary angiographic examination in Heart Center, Military Hospital 103 from January 2020 to June 2021. Results: The average age was $65.8 \pm 11.2$ years, male accounted for $76.8 \%$. The serum NT-proBNP levels was 82.2 to $871.5 \mathrm{pg} / \mathrm{mL}$. Median (25th-75th percentiles) was $242.7 \mathrm{pg} / \mathrm{mL}$. Medium NT-proBNP levels in the group with 2-vessel lesions $(310.9 \mathrm{pg} / \mathrm{ml})$ and 3-vessel lesions $(746.1 \mathrm{pg} / \mathrm{ml})$ was significantly higher than in the group with 1-vessel lesion (89.2 $\mathrm{pg} / \mathrm{ml})(\mathrm{p}<0.05)$. Medium NT-proBNP levels in the group with SYNTAX score < $23(214.8 \mathrm{pg} / \mathrm{ml})$ was significantly lower than in the group with SYNTAX score $\geq 23(1124.7 \mathrm{pg} / \mathrm{ml})(p<0.05)$. SYNTAX score was positively correlated with serum NT-proBNP levels $(r=0.62 ; p<0.05)$. The cut-off value of NT-proBNP concentration to predict SYNTAX score $\geq 23$ was $496.85 \mathrm{pg} / \mathrm{ml}$, sensitivity $75 \%$, specificity $77.4 \%$ $(p<0.05)$. Conclusion: The serum NT-proBNP levels of patients with acute MI were quite strongly correlated with severity of coronary lesions assessed by SYNTAX II score.

Keywords: Acute Myocardial Infarction, NTproBNP, SYNTAX II score.

\section{I. ĐẶT VẤN ĐỀ}

NMCT cấp là một trong những nguyên nhân gây tử vong hàng đầu ở Mỹ và các nước châu Âu, ước tính có khoảng một triệu BN nhập viện mối năm khoảng 200.000 đến 300.000 BN tử vong mỗi năm vì NMCT cấp [4]. Ở Việt Nam, số
BN NMCT cấp đang có xu hướng gia tăng. Theo thống kê tại Viện Tim mạch Quốc gia Việt Nam BN nhồi máu cơ tim cấp đã tăng từ $2 \%$ (năm 2001) đến 7\% (năm 2007) [3]. Bệnh để lại nhiều biến chứng nặng nề bao gồm: biến chứng cơ học (thủng vách liên thất, thành tự do của tim, hở van hai lá cấp tính) đến các rối loạn nhịp nguy hiểm và cuối cùng là tử vong.

Peptide lợi niệu thải natri typ-B (B-type natriuretic peptide - BNP) là một chất do tế bào cơ tim tiết ra. Tiền chất của BNP (ProBNP) có 108 acid amin, sau đó ProBNP bi thủy phân làm 2 chuỗi peptide: chuỗi amino tận cùng (NTproBNP) và chuỗi có gốc carboxyl tận cùng (BNP). Từ tình trạng căng giãn cơ tim và tái định dạng thất đến rối loạn chức năng tâm thu và/hoặc tâm trương là cơ chế chính gây phóng thích NT-proBNP. NT-proBNP được biết đến là dấu ấn sinh học có giá trị chẩn đoán và tiên lượng trong suy tim.

Trong thời gian gần đây, NT-proBNP huyết thanh đã được nhiều nghiên cứu chứng minh là có liên quan đến số lượng, mức độ tổn thương ĐMV thông qua thang điểm SYNTAX II, từ đó có vai trò trong tiên lượng tử vong và các biến cố ở BN NMCT cấp, [1],[5]. Xuất phát từ những vấn đề trên, nghiên cứu của chúng tôi nhằm mục tiêu: Đánh giá mối liên quan giữa nồng độ NT proBNP huyết thanh với mức độ tổn thương động mạch vành bằng thang điểm SYNTAX II ở bệnh nhân nhồi máu cơ tim cấp.

\section{II. ĐỐI TƯỢNG VÀ PHƯƠNG PHÁP NGHIÊN CỨU}

1. Đối tượng nghiên cứu. $69 \mathrm{BN}$ được chẩn đoán xác định NMCT cấp được chụp và can thiệp ĐMV qua da tại Trung Tâm Tim mạch, Bệnh viện Quân y 103 từ 1/2020 đến tháng 6/2021.

1.1. Tiêu chuẩn lựa chọn. $B N$ được chẩn đoán xác định nhồi máu cơ tim cấp theo Định nghĩa toàn cầu lần thứ IV 2018 [8]: BN có tình trạng tổn thương cơ tim cấp với triệu chứng của thiếu máu cơ tim cục bộ cấp và sự tăng Troponin với ít nhất một giá trị trên bách phân vị thứ 99 , kèm theo ít nhất một trong các dấu hiệu sau:

- Có triệu chứng cơ năng của thiếu máu cơ tim.

- Biến đổi thiếu máu cục bộ mới trên điện tâm đồ (đoạn ST, sóng T).

- Xuất hiện sóng Q bệnh lý.

- Bằng chứng hình ảnh về sự xuất hiện hình ảnh cơ tim không còn sống hoặc rối loạn vận động vùng

- Phát hiện huyết khối động mạch vành.

\subsection{Tiêu chuẩn loai trừ}

- Có bệnh tim bẩm sinh, bệnh van tim. 
- Có suy tim mạn tính.

- Viêm cơ tim cấp.

- Tách thành động mạch chủ cấp.

- Suy chức năng gan, thận mức độ nặng.

- Đang mắc các bệnh nhiễm trùng toàn thân.

- BN không đồng ý tham gia nghiên cứu.

2. Phương pháp nghiên cứu

- Thiết kế nghiên cứu: mô tả cắt ngang, lấy mẫu thuận tiện.

- Cách bước tiến hành nghiên cứu:

+ Bước 1 (Lựa chọn BN)

. Các BN sau khi chẩn đoán xác định NMCT cấp, thỏa mãn tiêu chuẩn lựa chon và không có tiêu chuẩn loại trừ được đưa vào nghiên cứu.

+ Bước 2 (Làm các xét nghiệm, tính điểm SYNTAX II)

.Định lượng nồng độ NT-proBNP huyết thanh.

.Đánh giá tổn thương mạch vành dựa trên kết quả chụp ĐMV cấp cứu: số nhánh động mạch tổn thương, mức độ hẹp, và tính điểm SYNTAX II bằng phần mềm SYNTAX Score II.

Bước 3 (Thu thập và xử lý số liệu)

.Số liệu được lưu trữ và xử lý bằng phần mềm SPSS 22.0.

.Nồng độ NT-proBNP phân phối không chuẩn, được mô tả bằng trung vị

.Kiểm định sự khác biệt nồng độ NT-proBNP theo các biến số phân loại là kiểm định phi tham số bằng phép kiểm Mann-Whitney U.

.Xác định sự tương quan giữa nồng độ NTproBNP máu và các biến số bằng hệ số tương quan Spearman.

.Vẽ đường cong ROC và tìm diên tích dưới đường cong ROC của NT-proBNP. Xác định điểm cắt của NT-proBNP tại nơi có giá trị dự báo mức điểm SYNTAX > 23 cao nhất (tỷ lệ ẩm tính giả và dương tính giả thấp nhất).

.Các phép so sánh, hệ số tương quan có ý nghĩa thống kê khi giá trị p $<0,05$.

\section{KẾT QUẢ NGHIÊN CỨU}

Tuổi trung bình là: $65,8 \pm 11,2$ năm. Tỷ lệ BN $>65$ tuổi chiếm $47,8 \%$. Nam giới chiếm tỳ lệ $76,8 \%$, nữ giới $23,2 \%$, tỷ lệ nam/nữ = 3,3/1.

Phương trình hồi quy tuyến tính giữa điểm GRACE và nồng độ NT-proBNP:

$$
\text { SYNTAX = 0,004 (NT- proBNP) }+14
$$

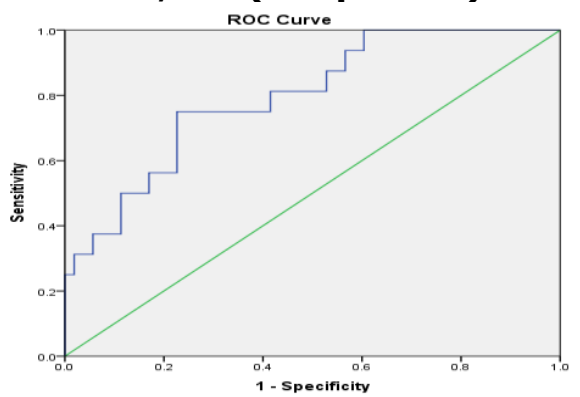

Biểu đồ 1. Đường cong ROC của nồng độ NT-proBNP và tốn thương ĐMV ở nhóm SYNTAX $\geq 23$.

Nhận xét: Diện tích dưới đường cong $A \cup C=0,796$ với $p<0,005$.

Bảng 1. Liên quan giứa nồng độ NT-proBNP và số lượng ĐMV tổn thương

\begin{tabular}{|c|c|c|c|}
\hline \multirow{2}{*}{$\begin{array}{c}\text { Số lương ĐMV } \\
\text { tổn thương }\end{array}$} & \multicolumn{2}{|c|}{ Nồng độ NT-proBNP (pg/ml) } & \multirow[b]{2}{*}{ p } \\
\hline & Số lượng BN (n) & Trung vi & \\
\hline 1 mạch (1) & 20 & $89,2(29,8 ; 258,3)$ & $P_{(1)-(2)}<0,05$ \\
\hline 2 mạch (2) & 31 & $310,9(116,8 ; 802,5)$ & $P_{(2)-(3)}>0,05$ \\
\hline 3 mạch (3) & 18 & $746,1(179,5 ; 3526,8)$ & $P_{(1)-(3)}<0,05$ \\
\hline Chung & 69 & $242,7(82,2 ; 871,5)$ & \\
\hline
\end{tabular}

Nhận xét. Nồng độ NT-proBNP huyết thanh nhóm tốn thương 1 nhánh ĐMV thấp hơn nhóm tổn thương 2 nhánh và 3 nhánh có ý nghĩa.

Bảng 2. Liên quan giữa nồng độ NT-proBNP với vị trí ĐMV thủ phạm

\begin{tabular}{|c|c|c|c|}
\hline \multirow{2}{*}{$\begin{array}{c}\text { Nhánh ĐMV thủ } \\
\text { phạm }\end{array}$} & \multicolumn{2}{|c|}{ Nồng độ NT-proBNP (pg/ml) } & \multirow[b]{2}{*}{$\mathbf{p}$} \\
\hline & Số lượng BN (n) & Trung vi & \\
\hline Liên thất trước (1) & 32 & $526,1(142,2 ; 1471)$ & $P_{(1)-(2)}>0,05$ \\
\hline Mũ (2) & 6 & $380,5(205,7 ; 793,2)$ & $P_{(2)-(3)}>0,05$ \\
\hline Vành phái (3) & 30 & $133,5(45,7 ; 382,7)$ & $P_{(1)-(3)}<0,05$ \\
\hline
\end{tabular}

Nhận xét: Nồng độ NT-proBNP ở nhóm có động mạch thủ phạm là động mạch liên thất trước cao hơn nhóm động mạch vành phải có ý nghĩa.

Bảng 3. Liên quan giữa nồng độ NT-proBNP và điểm SYNTAX

\begin{tabular}{|c|c|c|c|}
\hline \multirow{2}{*}{ Điểm SYNTAX } & \multicolumn{2}{|c|}{ Nồng độ NT-proBNP (pg/ml) } & \multirow{2}{*}{ p } \\
\cline { 2 - 3 } & Số lượng BN (n) & Trung vị & \multirow{2}{*}{$0<0,05$} \\
\hline$<23$ & 53 & $214,8(61,3 ; 456,1)$ & \\
\hline 23 & 16 & $1124,7(313,6 ; 3852,3)$ & \\
\hline$r$ & \multicolumn{2}{|c}{0,627} \\
\hline
\end{tabular}


Nhận xét: Nồng độ NT-proBNP huyết thanh ở nhóm BN có điểm SYNTAX < 23 thấp hơn nhóm SYNTAX $\geq 23$ (tổn thương phức tạp) có ý nghĩa. Điếm SYNTAX có mối tương quan thuận khá chặt với nồng độ NT-proBNP.

Bảng 4. Lứa chọn điểm cắt của NTproBNP dư báo điểm SYNTAX $\geq 23$

\begin{tabular}{|c|c|c|c|}
\hline $\begin{array}{c}\text { NT- } \\
\text { proBNP } \\
(\mathrm{pg} / \mathrm{ml})\end{array}$ & Độ nhạy & $\begin{array}{c}\text { Độ đặc } \\
\text { hiệu }\end{array}$ & Chỉ số J \\
\hline 413.6 & 0.75 & 0.736 & 0.486 \\
\hline 456.05 & 0.75 & 0.755 & 0.505 \\
\hline $\mathbf{4 9 6 . 8 5}$ & 0.75 & 0.774 & $\mathbf{0 . 5 2 4}$ \\
\hline 548.1 & 0.688 & 0.774 & 0.462 \\
\hline
\end{tabular}

Nhân xét: Điểm cắt được xác định dựa vào mức nổng độ NT - proBNP có độ nhạy và độ đặc hiệu cao nhất (chỉ số J-Youden Index cao nhất) là 496,85 pg/ml.

\section{BÀN LUẬN}

Tuổi trung bình của đối tượng nghiên cứu là $65,8 \pm 11,2$ năm. Các kết quả nghiên cứu trong và ngoài nước cho thấy NMCT cấp thường gặp ở người cao tuổi. Theo nghiên cứu của Đinh Đức Huy tuổi trung bình là $65,6 \pm 13,3$ năm [2], Khan và cộng sự: 66,5 $\pm 12,7[5]$.

Khi so sánh nồng độ NT-proBNP theo số lượng ĐMV bị tổn thương (Bảng 1), chúng tôi thấy NT-proBNP ở nhóm tổn thương 2, 3 mạch cao hơn ở nhóm tổn thương 1 mạch có ý nghĩa. Kết quả này tương tự với nghiên cứu của tác giả Trần Viết An cũng cho thấy sự gia tăng nồng độ NT-proBNP theo số lượng ĐMV tổn thương [1].

Khi so sánh nồng độ NT-proBNP theo vị trí động mạch thủ phạm, chúng tôi thây có sự khác biệt có ý nghĩa giữa 2 nhóm động mạch liển thất trước $(526,1 \mathrm{pg} / \mathrm{ml})$ và động mạch vành phải $(133,5 \mathrm{pg} / \mathrm{ml})$. Kết quả nghiên cứu của chúng tôi cũng phù hợp với kết quả của tác giả Sarak: nông độ NT-proBNP ở nhóm động mạch thủ phạm là động mạch liên thất trước $2673 \mathrm{pg} / \mathrm{ml}$ cao hơn nhóm động mạch vành phải (1644 $\mathrm{pg} / \mathrm{ml}), \quad p<0,001$ [7]. Sự khác biệt này có thể giải thích là do động mạc liên thất trước chi phối một khối lượng lớn cơ thất trái mà NT-proBNP, được tiết chủ yếu ở cơ thất và một lượng nhỏ ở nhĩ.

Trong thực hành lâm sàng, điểm SYNTAX II để đánh giá mức độ tổn thương ĐMV. Trong đó, điểm SYNTAX bằng 23 rất quan trọng, giúp xác định chiến lược điều trị tái tưới máu bằng can thiệp ĐMV qua da hoặc phẫu thuật bắc cầu nối chủ vành. Kết quả (Bảng 3) thây nồng độ NTproBNP ở nhóm điểm SYNTAX $\geq 23$ (trung vị: $1124,7 \mathrm{pg} / \mathrm{ml}$ ) cao hơn nhóm SYNTAX <23
$(214,8$ pg/ml) có ý nghĩa. Kết quả này cũng phù hợp với nghiên cứu của Sarak và cộng sự trên 405 BN NMCT cấp: NT-proBNP ở các nhóm có điểm SYNTAX $\geq 23$ cao hơn nhóm SYNTAX $<23$ có ý nghĩa, $p<0,001$ [7]. Một nghiên cứu khác của tác giả Kurtul trên 509 BN cũng cho kết quả tương tự [6]. Khi phân tích tương quan giữa NTproBNP huyết thanh và điểm SYNTAX, chúng tôi thấy có sự tương quan thuận khá chặt chẽ $(r=$ $0,627, p<0,05)$. Điểm cắt nồng độ NT-proBNP huyết thanh để dự báo điểm SYNTAX $\geq 23$ dựa vào phân tích đường cong ROC là $496.85 \mathrm{pg} / \mathrm{ml}$ với độ nhạy $75 \%$ và độ đặc hiệu 77,4\% (AUC = $0,796 ; p<0,005)$. Trong nghiên cứu của Sarak, điểm cắt nồng độ NT-proBNP huyết thanh để dự báo điểm SYNTAX >32 là $1719 \mathrm{pg} / \mathrm{ml}$, độ nhạy $70 \%$, độ đặc hiệu $63 \%(A \cup C=0,699)[6]$. Nghiển cứu của tác giả Kurtul cũng cho thấy điểm cắt nồng độ NT-proBNP huyết thanh ở mức tương đương để dự báo điểm SYNTAX>32: $1614 \mathrm{pg} / \mathrm{ml}$ với độ nhạy $75 \%$ và độ đặc hiệu $68 \%$ (AUC = $0.761, \mathrm{P}<.001)$ [6].

\section{KẾT LUÂN}

Qua nghiên cứu 69 bệnh nhân nhồi máu cơ tim cấp chúng tôi thấy nồng độ NT-proBNP có tương quan khá chặt chẽ với mức độ tổn thương động mạch vành theo thang điểm SYNTAX II và điểm cắt của nồng độ NT-proBNP dự báo điểm SYNTAX $\geq 23$ là 496,85 pg/ml.

\section{TÀI LIẸU THAM KHẢO}

1. Trân Viết An. Nghiên cứu vai trò của NT-proBNP huyết thanh trong đánh giá tổn thương động mạch vành và tiên lượng hội chứng vành cấp. Luận án Tiến sĩ Y học. Đại học Y Dược Huế. 2011.

2. Đinh Đức Huy. Nghiên cứu nồng độ copeptin huyết thanh ở BN nhồi máu cơ tim cấp. Luận án Tiến sĩ Y học. Đại học Y Dược Huế. 2021.

3. Nguyến Lân việt. Thực hành bệnh tim mạch. Nhà xuất bản Y học. 2014;47-59.

4. Antman EM, Anbe DT, Armstrong PW, et al. ACC/AHA guidelines for the management of patients with ST-elevation myocardial infarctionexecutive summary: a report of the American College of Cardiology/American Heart Association Task Force on Practice Guidelines, J Am Coll Cardiol. 2004;44 (3):671-719.

5. Khan QS, Narayan $H$, Kelvin $H N$, et al. Nterminal pro-B-type natriuretic peptide complements the GRACE risk score in predicting early and late mortality following acute coronary syndrome. Clin Sci (Lond). 2009;117(1):31-9.

6. Kurtul A, Mikail Y, Sani NM, et al. N-Terminal Pro-Brain Natriuretic Peptide Level is Associated With Severity and Complexity of Coronary Atherosclerosis in Patients With Acute Coronary Syndrome. Clin Appl Thromb Hemost. 2016;22(1):69-76.

7. Sarak T, Karadeniz M. The relationship between 
serum NT-proBNP levels and severity of coronary artery disease assessed by SYNTAX score in patients with acute myocardial infarction. Turk J Med Sci. 2019;49(5):1366-1373.
8. Thygesen K, Alpert SJ, Jaffe SA, et al. (2018) Fourth universal definition of myocardial infarction (2018). Circulation. 2018;138(20):e618-e651.

\section{ĐĂC ĐIỂM LÂM SÀNG RỐI LOÂN SỰ THÍCH ỨNG VỚI PHẢN ỨNG TRÂM CẢM NGẮN}

\section{TÓM TẮT}

Nghiên cứu đặc điểm lâm sàng rối loạn sự thích ứng với phản ứng trầm cảm ngắn với mục tiêu mô tả đặc điểm lâm sàng rối loạn sự thích ứng với phản ứng trầm cảm ngắn. Bằng phương pháp mô tả cắt ngang ở 66 người bệnh điều trị nội trú tại Viện Sức khỏe Tâm thần Quốc Gia, bệnh viện Bạch Mai, được chẩn đoán chính xác rối loạn sự thích ứng với phản ứng trầm cảm ngắn (F43.20) theo tiêu chuẩn chẩn đoán của ICD 10. Kết quả: phần lớn người bệnh rối loạn sự thích ứng với phản ứng trầm cảm ngắn găp ở đồ tuối từ $20-29$ và $30-39$ với tỉ lệ cùng bằng $27,3 \%$. Tuổi trung bình của nhóm người bệnh này là $33,6 \pm 13,9$. Sang chấn tâm lý trong nhóm nghiên cứu gặp nhiều nhất là những sang chấn trong công việc/học tập 69,7\%. Trong 3 triệu chứng chính của trầm cảm, triệu chứng giảm năng lươnng và tăng mệt mỏi là triệu chứng gặp nhiều nhẩt với tî lệ 80,3\%. Trong 7 triệu chứng phổ biến của trầm cảm, triệu chứng rối loạn giấc ngủ là triệu chứng thường gặp nhất với tỉ lệ 93,9\%. Không gặp triệu chứng có hành vi tự sát. Trong 8 triệu chứng cở thể của trầm cảm thì triệu chứng tỉnh giấc vào lúc sáng sớm hơn 2 giờ là triệu chứng gặp nhiêu nhất với tỉ lệ 93,9\%. Ít gặp nhất là triệu chứng chậm chạp tâm thần vận động $(39,4 \%)$.

Từ khoá: rối loạn sự thích ứng; trầm cảm;

\section{SUMMARY}

\section{CLINICAL FEATURES OF THE ADJUSTMENT DISORDER WITH BRIEF DEPRESSIVE REACTION}

The study aims to describe clinical features of adjustment disorder with brief depressive reaction. This was a cross-sectional descriptive study including 66 patients who were diagnosed with adjustment disorder with brief depressive reaction (F43.2) and admitted to the National Institute of Mental Health, Bach Mai hospital. Results: the majority of patients were at the age of $20-29$ and $30-39$ years old with the same rate of $27.3 \%$. The mean age of patients was $33.6 \pm$ 13.9. The most common psychological

\footnotetext{
${ }^{1}$ Đại học Y Hà Nội

${ }^{2}$ Viện Sức Khỏe Tâm Thần - Bênh Viện Bạch Mai

Chịu trách nhiệm chính: Dương Minh Tâm

Email: duongminhtam@hmu.edu.vn

Ngày nhận bài: 15.9.2021

Ngày phản biên khoa họ: 12.11.2021

Ngày duyệt bài: 23.11 .2021
}

\section{Trần Nguyễn Ngọc ${ }^{1,2}$, Dương Minh Tâm ${ }^{1,2}$}

trauma was work orstudy trauma (69.7\%). Among the 3 main symptoms of depression, symptoms of decreased energy and increased fatigue were the most commonwith the rate of $80.3 \%$. Among 7 common symptoms of depression sleep disorder was account for the highest proportion (93.9\%). No symptom of suicidal behavior was found. Among 8 physical symptoms of depression, waking up in the morning earlier than 2 hours occurred most frequently $(93.9 \%)$. The less common symptom of this disorder was psychomotor retardation (39.4\%).

Keywords: Adjustment disorders; depression.

\section{I. ĐẶT VẤN ĐỀ}

Rối loạn sự thích ứng với phản ứng trầm cảm ngắn (F43.20) là một trạng thái trầm cảm nhẹ nhất thời có thời gian kéo dài không quá một tháng kể từ khi tiếp xúc với sang chấn tâm lý xã hội. Những sang chấn tâm lý này không phải là loại bất thường hoặc có tính thảm họa như các mầu thuẫn giữa cá nhân, người thân yêu mất hoăcc bị bệnh, thất nghiệp, khó khăn về kinh tế, hoặc bản thân bị. ${ }^{1}$ Tỉ lệ mắc dao động từ $2 \%$ đến $8 \%$ đối với trẻ em và̀ từ $12,5 \%$ đến $34 \%$ đối với thanh thiếu niên. ${ }^{2}$ Trong thực hành lâm sàng, chẩn đoán rối loạn sự thích ứng với phản ứng trầm cảm ngắn vẫn còn khó khăn do dễ nhầm lẫn với các biểu hiện của giai đoạn trầm cảm hoặc rối loạn cảm xúc lưỡng cực trầm cảm. Tại Việt Nam, đã có một số đề tài nghiên cứu về các rối loạn rối loạn sự thích ứng nhưng chưa có đề tài nghiên cứu về đặc điểm lâm sàng rối loạn sự thích ứng với phản ứng trầm cảm ngắn. Vì vậy với mong muốn làm rõ đặc điểm lâm sàng và bổ sung thêm dữ liệu về phản ứng trầm cảm ngắn chúng tôi thực hiện nghiên cứu với mục tiêu "Mô tả đặc điểm lâm sàng rối loạn sự thích ứng với phản ứng trầm cảm ngắn".

II. ĐỐI TƯợNG VÀ PHƯƠNG PHÁP NGHIÊN CỨU

2.1. Thiết kế nghiên cứu. Thiết kễ được sử dụng là nghiên cứu mô tả cắt ngang.

\subsection{Thời gian, đối tượng và địa điểm} nghiên cứu

2.2.1. Thời gian nghiên cứu: Tháng 8 năm 2020 đến tháng 8 năm 2021. 